\title{
ANALISIS KEMAMPUAN KOMUNIKASI MATEMATIS SISWA DALAM MENYELESAIKAN SOAL OPEN ENDED PADA MATERI ARITMETIKA SOSIAL KELAS VII SMP
}

\author{
Sukma Ana Anggraeni ${ }^{1}$,Evi Widayanti ${ }^{2}$ \\ ${ }^{1,2}$ STKIP Bina Insan Mandiri (Pendidikan Matematika) \\ e-mail korespondensi: eviwidayanti@stkipbim.ac.id
}

\section{RIWAYAT ARTIKEL}

Diterima(04-12-2019)

Revisi (07-12-2019)

Diterbitkan(30-12-2019)

\section{ABSTRAK}

Kemampuan komunikasi matematis siswa dalam menyelesaikan soal open ended yang berkaitan dengan permasalahan sehari-hari sangatlah penting. Penelitian ini bertujuan untuk mengukur, menganalisis, dan mendeskripsikan kemampuan komunikasi matematis siswa dalam menyelesaikan soal open-ended pada materi aritmetika sosial kelas VII SMP. Jenis penelitian adalah penelitian deskriptif kualitatif. Subjek penelitian ada 36 siswa kelas VII-H di SMPN 28 Surabaya dan diambil 6 siswa dari kategori tinggi, sedang, dan rendah. Teknik pengumpulan data yang digunakan adalah tes dan wawancara. Tes berupa soal open-ended materi aritmetika sosial. Wawancara untuk menganalisis kemampuan komunikasi matematis secara lisan menggunakan wawancara semi terstruktur. Subjek dianalisis berdasarkan 3 indikator yaitu: 1) menyatakan peristiwa sehari-hari dalam bahasa atau simbol matematika (IDK 1), 2) menjelaskan ide, situasi dan relasi matematik, secara lisan dan tulisan dengan benda nyata, gambar, grafik dan aljabar (IDK 2), dan 3) menganalisis dan mengevaluasi pemikiran matematis dan strategi yang dipakai orang lain (IDK 3).

Hasil penelitian menunjukkan bahwa kemampuan komunikasi matematis siswa dalam menyelesaikan soal open-ended pada materi aritmetika sosial kelas VII SMP dapat dikatakan baik, karena (1) siswa pada kategori tinggi mampu mencapai Indikator 1 (IDK 1), IDK 2, dan IDK 3, (2) siswa pada kategori sedang mampu mencapai IDK 1 dan IDK 2, tetapi kurang mampu pada IDK 3, dan (3) siswa pada kategori rendah mampu mencapai IDK 1, kurang mampu pada IDK 2, dan belum mampu pada IDK 3.

Kata Kunci: Aritmetika Sosial, Kemampuan Komunikasi Matematis, Open Ended. 


\begin{abstract}
Students mathematical communication skills in solving open-ended related to daily problems are very important. This research aims to measure, analyze, and describe students mathematical communication skills in solving open-ended questions on social arithmetic in seventh grade junior high school.This type of research is a qualitative descriptive. Subjects of this research is 36 students of seventh grade (VII-H) at SMPN 28 Surabaya and 6 students taken from high, medium, and low categories. Data collection techniques used tests and interviews. Test for open-ended questions on social arithmetic. Interviews to analyze mathematical communication skills verbally using semi structured interviews. The subjects were analyzed based on 3 indicators namely: 1) Stating the contextual problems in language and mathematical symbols (IDK 1), 2) Explaining ideas, situations, and mathematical relations, verbally and in writing with real objects, pictures, graphics, and algebra (IDK 2), and 3) Analyze and evaluate the mathematical thinking and strategies of others (IDK 3).

The results showed that students mathematical communication skills in solving open-ended questions on social arithmetic in seventh grade junior high school could be said to be good, because (1) students in the high categories of able to reach indicators 1 (IDK 1), IDK 2, and IDK 3, (2) students in the medium categories were able to achieve IDK 1 and IDK 2, but are less able to IDK 3, and (3) students in the low categories are able to IDK 1, less able to IDK 2, and have not been able to IDK3.

Keywords: Communication Mathematical Skills, Open-Ended, Social Arithmetic.
\end{abstract}

\title{
1. Pendahuluan
}

Komunikasi adalah langkah awal dalam mengenal suatu hal. Melalui komunikasi kita dapat memahami apa yang terjadi disekitar kita. Termasuk dalam memahami dan mempelajari ilmu matematika, juga membutuhkan komunikasi. Menurut National Council of Teachers of Mathematics (NCTM) (2000: 29), bahwa standar utama tujuan pelajaran matematika adalah agar siswa mempunyai kemampuan: 1) pemecahan masalah; 2) penalaran; 3) komunikasi; 4) koneksi; dan 5) representasi. Komunikasi matematis siswa merupakan hal yang dapat menentukan pemahaman siswa dalam menguasai suatu materi baik dalam bentuk lisan maupun tertulis. Kemampuan komunikasi matematis siswa masih tergolong rendah (Wijayanto, dkk, 2018: 97). Hal itu disebabkan siswa yang terbiasa dengan perhitungan, namun kurang dalam penerapannya.

Berbagai sumber juga menyebutkan tentang peran penting komunikasi dalam pembelajaran matematika. Menurut Baroody (dalam Umar, 2012) sedikitnya ada 2 alasan penting yang menjadikan komunikasi dalam pembelajaran matematika perlu menjadi fokus perhatian yaitu (1) mathematics as language; matematika tidak hanya sekedar alat bantu berpikir (a tool to aid thinking), alat untuk menemukan pola, atau me- 
nyelesaikan masalah namun matematika juga "an invaluable tool for communicating a variety of ideas clearly, precisely, and succintly," dan (2) mathematics learning as social activity; sebagai aktivitas sosial, dalam pembelajaran matematika, interaksi antar siswa, seperti juga komunikasi guru- siswa merupakan bagian penting untuk "nurturing children's mathematical potential”. Bahkan menurut Cai (dalam Umar, 2012) “communication is considered as the means by which teachers and students can share the process of learning, understanding, dan doing mathematics."

Kemampuan komunikasi matematis merupakan suatu kemampuan dalam menyampaikan sesuatu yang diketahuinya melalui peristiwa dialog atau saling hubungan yang terjadi di lingkungan kelas, dimana terjadi pengalihan pesan mengenai materi matematika yang dipelajari siswa baik dalam konsep maupun pemecahan masalah. Pihak yang terlibat dalam peristiwa komunikasi di dalam kelas adalah guru dan siswa dalam bentuk tertulis maupun lisan (Herdian, 2010). Berdasarkan pengertian tersebut dapat disimpulkan bahwa kemampuan komunikasi matematis adalah kemampuan siswa dalam mengemukakan, mengembangkan, mendeskripsikan ide-ide, gagasan, pikiran matematika dalam simbol, gambar, tabel, persamaan, atau bahasanya sendiri dalam bentuk lisan maupun tulisan. Adapun indikator kemampuan komunikasi matematis menurut beberapa ahli sebagai berikut.

Tabel 1. Indikator Kemampuan Komunikasi Matematis Menurut Para Ahli

\begin{tabular}{|c|c|c|}
\hline $\begin{array}{c}\text { NCTM } \\
(2000: 60,2003: 2) \\
\end{array}$ & $\begin{array}{c}\text { Sumarmo } \\
\text { (Elida, 2012: 180-181) }\end{array}$ & $\begin{array}{l}\text { Hodiyanto } \\
(2017: 15) \\
\end{array}$ \\
\hline $\begin{array}{l}\text { Mengorganisasi dan mengga- } \\
\text { bungkan pemikiran matematis } \\
\text { dan mengomunikasikan kepa- } \\
\text { da siswa lain }\end{array}$ & $\begin{array}{l}\text { Menyatakan peristiwa seha- } \\
\text { ri-hari dalam bahasa atau } \\
\text { simbol matematika }\end{array}$ & $\begin{array}{l}\text { Menyajikan ide dalam } \\
\text { bentuk tulisan atau dengan } \\
\text { bahasa sendiri }\end{array}$ \\
\hline $\begin{array}{l}\text { Mengekspresikan ide-ide ma- } \\
\text { tematika secara koheren dan } \\
\text { jelas kepada teman, guru, dan } \\
\text { orang lain }\end{array}$ & $\begin{array}{l}\text { Membaca dengan pemahaman } \\
\text { suatu presentasi matematika } \\
\text { tertulis }\end{array}$ & $\begin{array}{l}\text { Menjelaskan ide atau solu- } \\
\text { si dari permasalahan ma- } \\
\text { tematika dalam bentuk } \\
\text { gambar }\end{array}$ \\
\hline $\begin{array}{l}\text { Menganalisis dan mengevalu- } \\
\text { asi pemikiran matematis dan } \\
\text { strategi yang dipakai orang } \\
\text { lain }\end{array}$ & $\begin{array}{l}\text { Menghubungkan benda nyata, } \\
\text { gambar, dan diagram ke dalam } \\
\text { ide matematika }\end{array}$ & $\begin{array}{l}\text { Menyatakan masalah seha- } \\
\text { ri-hari dalam model mate- } \\
\text { matika }\end{array}$ \\
\hline $\begin{array}{l}\text { Menggunakan bahasa mate- } \\
\text { matika untuk mengekspresi- }\end{array}$ & $\begin{array}{l}\text { Menjelaskan ide, situasi dan } \\
\text { relasi matematik, secara lisan }\end{array}$ & \\
\hline
\end{tabular}




\begin{tabular}{ll}
\hline $\begin{array}{l}\text { kan ide-ide matematika secara } \\
\text { benar }\end{array}$ & $\begin{array}{l}\text { dan tulisan dengan benda } \\
\text { nyata, gambar, grafik dan al- } \\
\text { jabar }\end{array}$ \\
\hline Membuat konjektur, menyu- \\
sun argumen, merumuskan \\
definisi dan generalisasi \\
\hline Mendengarkan, berdiskusi, \\
dan menulis tentang matema- \\
tika \\
Menjelaskan dan membuat \\
pertanyaan tentang matemati- \\
ka yang dipelajari \\
\hline
\end{tabular}

Untuk mengembangkan kemampuan komunikasi matematis dalam diri siswa, maka diperlukan suatu cara tertentu yang sesuai dengan kurikulum saat ini. Beberapa cara yang ditulis oleh Umar (2012: 4), antara lain: (1) pemberian soal yang bersifat open ended task, (2) melakukan cooperative learning, (3) menerapkan strategi think-talk-write, (4) penggunan metode proyek, dan sebagainya. Cara tersebut dapat menutut siswa menerapkan kemampuan komunikasi matematis yang dimilikinya. Dalam penelitian ini peneliti menggunakan soal open-ended dengan memuat materi aritmetika sosial kelas VII SMP dalam melatih kemampuan komunikasi matematis siswa.

Berdasarkan penelitian yang dilakukan oleh Yusuf, dkk (2009: 55) dengan judul "Pengembangan Soal-Soal Open-Ended pada Pokok Bahasan Segitiga dan Segiempat di SMP" memperoleh hasil bahwa soal open-ended memberikan dampak positif pada hasil tes siswa. Masalah open-ended merupakan salah satu cara dalam melatih kemampuan komunikasi matematis siswa. Masalah open-ended adalah suatu permasalahan yang dimaksudkan mempunyai banyak jawaban yang benar. Sedangkan pembelajaran yang menyajikan suatu permasalahan yang memiliki metode atau penyelesaian lebih dari satu disebut pembelajaran open-ended (Ruslan dan Santoso, 2013: 141-142). Dapat disimpulkan bahwa soal open-ended merupakan cara dalam menyelesaikan, memecahkan, dan menemukan jawaban dari suatu pertanyaan yang terbuka dengan memiliki banyak cara yang mengarah pada satu jawaban atau banyak jawaban.

Berdasarkan uraian diatas, maka dilakukan penelitian dengan judul "Analisis Kemampuan Komunikasi Matematis Siswa dalam Menyelesaikan Soal Open-Ended pada Materi Aritmetika Sosial". Adapun rumusan masalah yang ditampilkan adalah "Bagaimana kemampuan komunikasi matematis siswa dalam menyelesaikan soal open-ended 
pada materi aritmetika sosial kelas VII SMP?". Tujuan penelitian adalah untuk mengukur, menganalisis, dan mendeskripsikan kemampuan komunikasi matematis siswa dalam menyelesaikan soal open-ended pada materi aritmetika sosial kelas VII SMP. Penelitian dibatasi dengan menggunakan indikator kemampuan komunikasi matematis sebagai berikut.

Tabel 2. Indikator Kemampuan Komunikasi Matematis Yang Digunakan Peneliti

\begin{tabular}{|c|c|c|}
\hline Kode & Indikator & Hal yang Dianalisis \\
\hline IDK 1 & $\begin{array}{l}\text { Menyatakan peristiwa sehari-hari da- } \\
\text { lam bahasa atau simbol matematika }\end{array}$ & $\begin{array}{l}\text { Dilihat dari siswa dalam menuliskan apa } \\
\text { yang mereka pahami dan ketahui }\end{array}$ \\
\hline IDK 2 & $\begin{array}{l}\text { Menjelaskan ide, situasi dan relasi ma- } \\
\text { tematik, secara lisan dan tulisan dengan } \\
\text { benda nyata, gambar, grafik dan aljabar }\end{array}$ & $\begin{array}{l}\text { Dilihat dari siswa bagaimana membuat } \\
\text { kesimpulan mengenai hasil yang mereka } \\
\text { peroleh serta menjelaskan ide mereka } \\
\text { secara lisan }\end{array}$ \\
\hline IDK 3 & $\begin{array}{l}\text { Menganalisis dan mengevaluasi pemi- } \\
\text { kiran matematis dan strategi yang di- } \\
\text { pakai orang lain }\end{array}$ & $\begin{array}{l}\text { Dilihat dari bagaimana sikap siswa da- } \\
\text { lam menjawab pertanyaan jika diberikan } \\
\text { suatu alternatif jawaban yang lain dan } \\
\text { cara menganalisis serta mengevaluasinya }\end{array}$ \\
\hline
\end{tabular}

Keterangan: IDK : Indikator

Peneliti memilih indikator tersebut dikarenakan hal di atas cukup tepat dalam materi aritmetika sosial yang berhubungan dengan permasalahan sehari-hari, menjelaskan cara menyelesaikan masalah dan menganalisis pemikiran siswa dalam memecahkan masalah tersebut.

Peneliti berharap agar penelitian ini memberikan manfaat bagi pendidik dan siswa untuk terus mengembangkan kemampuan komunikasi matematis dalam menyelesaikan peristiwa sehari-hari dengan tipe soal yang berbeda-beda.

\section{Metode Penelitian}

Jenis penelitian ini adalah penelitian deskriptif kualitatif. Berikut rancangan penelitian dalam penelitian ini. 


\begin{tabular}{|c|c|c|}
\hline $\begin{array}{l}\text { Rancangan Penda- } \\
\text { huluan. } \\
\text { - } \quad \text { Menyiapkan } \\
\text { instrumen pe- } \\
\text { nelitian. } \\
\text { - } \quad \text { Validasi in- } \\
\text { strumen pene- } \\
\text { litian } \\
\text { - Pemilihan ke- } \\
\text { las }\end{array}$ & $\begin{array}{ll}\text { Rancangan Inti. } \\
\text { - } & \text { Menguji soal } \\
& \text { tes } \\
\text { - } & \text { Memilih subjek } \\
& \text { penelitian di } \\
& \text { kelas } \\
-\quad & \text { Melaksanakan } \\
& \text { wawancara } \\
\text { terhadap subjek } \\
\text { penelitian }\end{array}$ & $\begin{array}{l}\text { Rancangan Analisis } \\
\text { Data. } \\
\text { - } \quad \text { Menganalisis } \\
\text { hasil soal tes } \\
\text { dan hasil wa- } \\
\text { wancara } \\
\text { menggunakan } \\
\text { analisis de- } \\
\text { skriptif kua- } \\
\text { litatif. }\end{array}$ \\
\hline
\end{tabular}

Gambar 1. Rancangan Penelitian

Subjek penelitian adalah siswa kelas VII-H di SMPN 28 Surabaya tahun ajaran 2018-2019 sebanyak 36 siswa. Pada penelitian deskriptif kualitatif, instrumen utama adalah peneliti sendiri. Teknik pengumpulan data menggunakan tes dan wawancara. Tes tulis dengan soal open-ended materi aritmetika sosial yang digunakan untuk menganalisis kemampuan komunikasi matematis siswa secara tertulis. Soal tes terdiri dari 3 butir soal open-ended yang telah divalidasi oleh ahli berkompeten.

Berikut soal tes open ended dengan tipe soal dan aspek keterbukaan.

Tabel 3. Tipe dan Aspek Keterbukaan Soal Tes Open Ended

\begin{tabular}{cll}
\hline $\begin{array}{c}\text { Nomor } \\
\text { Soal }\end{array}$ & $\begin{array}{c}\text { Tipe Soal menurut Sroyer (2013: } \\
\text { 34-35) }\end{array}$ & $\begin{array}{c}\text { Aspek Keterbukaan menurut Suherman } \\
\text { (dalam Herdiman, 2017: 198) }\end{array}$ \\
\hline $\mathbf{1}$ & Masalah praktis di kehidupan nyata & $\begin{array}{l}\text { Terbuka proses penyelesaiannya dan Ter- } \\
\text { buka hasil akhirnya }\end{array}$ \\
\hline $\mathbf{2}$ & $\begin{array}{l}\text { Soal untuk diselesaikan dengan data } \\
\text { yang tidak lengkap/ asumsi tersem- }\end{array}$ & $\begin{array}{l}\text { Soal untuk diselesaikan dengan data yang } \\
\text { tidak lengkap/ asumsi tersembunyi Terbu- }\end{array}$ \\
& $\begin{array}{l}\text { bunyi Terbuka proses penyelesaian- } \\
\text { ka proses penyelesaiannya dan Terbuka }\end{array}$ \\
& nya dan Terbuka hasil akhirnya & hasil akhirnya \\
\hline $\mathbf{3}$ & $\begin{array}{l}\text { Soal untuk diselesaikan dengan men- } \\
\text { jelaskan sebuah konsep/ prosedur }\end{array}$ & $\begin{array}{l}\text { Soal untuk diselesaikan dengan menje- } \\
\text { laskan sebuah konsep/ prosedur /kesalahan }\end{array}$ \\
& $\begin{array}{l}\text { /kesalahan Terbuka proses penyele- } \\
\text { saiannya dan Terbuka hasil akhirnya }\end{array}$ & buka hasil akhirnya \\
\hline
\end{tabular}

Soal tes yang diberikan, terlebih dahulu divalidasi oleh ahli yang kompeten dibidangnya. Soal tes telah divalidasi oleh 2 validator yang terdiri dari dua pakar atau ahli di bidangnya.

Wawancara yang digunakan adalah jenis wawancara semi terstruktur yang digu- 
nakan untuk menganalisis kemampuan komunikasi siswa secara lisan.

Tabel 4. Pedoman Wawancara

Indikator Kemampuan Komunikasi

\section{Pertanyaan}

\section{Matematis}

Menyatakan peristiwa seharihari dalam ba- 1. Apakah kamu mengerti yang dimaksud oleh hasa atau simbol matematika. soal ini (menyebutkan nomor)?

2. Jelaskan maksud dari soal ini (menyebutkan nomor)?

Menjelaskan ide, situasi dan relasi matematik, secara lisan dan tulisan dengan benda

1. Bagaimana cara kamu menjawab soal ini? nyata, gambar, grafik dan aljabar 2. Tuliskan kembali cara kamu dan jelaskan secara runtut?

Menganalisis dan mengevaluasi pemikiran 1. Apakah cara yang kamu gunakan ini sudah matematis dan strategi yang dipakai orang lain. dapat menyelesaikan soal ini?

2. Menurut kamu apakah ada cara yang lain lagi dalam menyelesaikan soal ini?

Teknik analisis data terdiri dari 3 tahapan sebagai berikut.

1) Reduksi data, pada tahap ini peneliti mengkategorikan hasil soal tes menjadi 3 kategori yaitu tinggi, sedang, dan rendah. Pengklasifikasian kategori berdasarkan menurut Subekti, Untarti, dan Muhammad (2016: 269).

Tabel 5. Klasifikasi Kategori

\begin{tabular}{cc}
\hline Rentang Nilai & Kategori \\
\hline$x \geq$ (nilai rata-rata + standar deviasi $)$ & Tinggi \\
\hline (nilai rata-rata - standar deviasi $)<x<$ (nilai rata-rata + standar deviasi) & Sedang \\
\hline$x \leq$ (nilai rata-rata - standar deviasi $)$ & Rendah \\
\hline
\end{tabular}

Keterangan: $x$ adalah nilai soal tes open ended

2) Pemaparan data, pada tahap ini hasil soal tes dan wawancara lebih diidentifikasi mendalam dalam setiap kategori disesuaikan dengan indikator kemampuan komunikasi matematis yang ditentukan sebelumnya.

3) Penarikan kesimpulan, pada tahap ini peneliti menarik kesimpulan dengan teknik triangulasi metode. Triangulasi metode yang digunakan adalah metode tes dan wawancara. Teknik triangulasi berfungsi mencocokan hasil soal tes dengan hasil wawancara.

\section{Hasil dan Pembahasan}

Data yang sudah diperoleh dianalisis dan dideskripsikan sesuai dengan indikator ke- 
mampuan komunikasi matematis yang telah ditentukan oleh peneliti. Hal tersebut dilakukan untuk mengetahui kemampuan komunikasi matematis siswa kelas VII-H di SMPN 28 Surabaya dalam menyelesaikan soal open-ended pada materi aritmetika sosial. Pada soal tes yang diberikan sebagian besar siswa dapat menyelesaikannya. Berikut hasil soal tes kemampuan komunikasi matematis siswa beserta klasifikasi kategori sesuai yang telah dipaparkan pada Tabel 2.

Tabel 6. Data Hasil Soal Tes Kemampuan Komunikasi Matematis

\begin{tabular}{clc}
\hline No & \multicolumn{1}{c}{ Data } & Nilai \\
\hline 1 & Nilai rata-rata & 74 \\
\hline 2 & Standar Deviasi & 21 \\
\hline 3 & Nilai terendah & 20 \\
\hline 4 & Nilai tertinggi & 100 \\
\hline 5 & Nilai rata-rata - standar deviasi & 53 \\
\hline 6 & Nilai rata-rata + standar deviasi & 95
\end{tabular}

Berdasarkan Tabel 6 di atas dapat diklasifikasi sesuai klasifikasi kategori sebelumnya. Berikut klasifikasi kategori dari data di atas.

Tabel 7. Klasifikasi Kategori dari Hasil Soal Tes

\begin{tabular}{cccc}
\hline Rentang Nilai & Kategori & Banyak Siswa & Persentase \\
\hline$x \geq 95$ & Tinggi & 4 & $11,11 \%$ \\
\hline $53<x<95$ & Sedang & 27 & $75,00 \%$ \\
\hline$x \leq 53$ & Rendah & 5 & $13,89 \%$ \\
\hline \multicolumn{2}{c}{ Jumlah siswa } & 36 &
\end{tabular}

Keterangan: $x$ adalah nilai soal tes siswa

Berdasarkan Tabel 7 di atas, peneliti memilih 2 siswa mewakili kategori tinggi, 2 siswa mewakili kategori sedang, dan 2 siswa mewakili kategori rendah. Berikut hasil pemilihan subjek penelitian.

Tabel 8. Hasil Pemilihan Subjek Penelitian

\begin{tabular}{cccc}
\hline No & Pengelompokan Kategori & Nilai Tes & Kode Siswa \\
\hline 1 & Tinggi & 100 & RM \\
\hline 2 & Tinggi & 100 & FD \\
\hline 3 & Sedang & 70 & DR \\
\hline 4 & Sedang & 70 & NG \\
\hline 5 & Rendah & 20 & DM \\
\hline 6 & Rendah & 50 & SI \\
\hline
\end{tabular}

Subjek penelitian yang sudah dipilih akan dianalisis dengan indikator kemampuan 
komunikasi matematis yang sudah ditentukan. Setiap butir soal memuat ketiga indikator tersebut, namun dalam menganalisis peneliti menentukan setiap indikator memuat satu soal. Pada indikator 1, soal yang dianalisis adalah nomor 1 . Pada indikator 2, soal yang dianalisis adalah nomor 2. Pada indikator 3, soal yang dianalisis adalah nomor 3 . Berikut hasil analisis pada setiap indikator.

1. Menyatakan peristiwa sehari-hari dalam bahasa atau simbol matematika. Pada indikator ini, soal yang akan dianalisis adalah soal nomor 1. Berikut soal nomor 1 .

1. Nayla, Rani, Samir, dan Toni sedang makan di Restoran Lesehan. Di
Restoran tersebut terdapat menu makanan dan minuman seperti di bawah ini.
\begin{tabular}{|c|c|c|c|}
\hline \multicolumn{3}{|c|}{ Makanan } & Minuman \\
\hline Nama & Harga & Nama & Harga \\
\hline Pangsit Bakso & Rp $30.000,00$ & Es Teh Jumbo & Rp $10.000,00$ \\
\hline Ayam Geprek & $\operatorname{Rp~} 25.000,00$ & Jus Jeruk & Rp $15.000,00$ \\
\hline Gurami Bakar & Rp $35.000,00$ & Jus Alpukat & Rp $20.000,00$ \\
\hline Nasi Liwet Komplit & $\operatorname{Rp~} 40.000,00$ & Kopi Tubruk & Rp $20.000,00$ \\
\hline CapCay Seafood & $\operatorname{Rp~} 38.000,00$ & Es Rainbow & Rp $25.000,00$ \\
\hline Tumis Kangkung Saus Tiram & $\operatorname{Rp~} 20.000,00$ & Milk Shake & Rp $20.000,00$ \\
\hline Sop Buntut & $\operatorname{Rp~} 35.000,00$ & Air Mineral & Rp $5.000,00$ \\
\hline
\end{tabular}

\footnotetext{
Di Restoran Lesehan ada diskon hari ini sebesar $20 \%$ untuk pembelian di atas Rp 200.000,00. Tentukan makanan dan minuman yang bisa dipesan oleh Nayla dan ketiga temannya masing-masing jika mereka ingin mendapatkan diskon tersebut! Jelaskan biaya yang harus mereka keluarkan!
}

Gambar 2. Soal Tes Nomor 1

Soal nomor 1 di atas telah diselesaikan oleh siswa dengan baik, hanya ada beberapa siswa yang belum lengkap dalam pengerjaannya. Subjek pada kategori tinggi yaitu subjek FD dan RM telah menuliskan hal yang diketahui dan dipahami. Mereka menuliskan langkah-langkah pengerjaan secara lengkap dan benar. Mereka juga mampu menjelaskan pengetahuan mengenai soal nomor 1 dan cara dalam menyelesaikan. Subjek pada kategori sedang yaitu DR dan NG telah menuliskan hal yang diketahui dan dipahami. Mereka menuliskan langkah-langkah pengerjaan secara lengkap tetapi masih ada kesalahan pada hasil akhir. Secara lisan DR dan NG telah mampu menjelaskan hal yang dimaksud oleh soal nomor 1. Subjek pada kategori rendah yaitu SI dan DM telah menuliskan hal yang diketahui dan dipahami dan mampu menjelaskan maksud dari soal nomor 1. Namun mereka ada kesalahan pada proses perhitungan. Dari penjelasan tersebut maka subjek pada kategori tinggi, sedang, dan rendah telah mampu menuliskan hal yang diketahui dan dipahami yang dimaksud oleh soal nomor 1 . 
2. Menjelaskan ide, situasi dan relasi matematik, secara lisan dan tulisan dengan benda nyata, gambar, grafik dan aljabar.

Pada indikator 2 soal yang dianalisis adalah soal nomor 2. Berikut bentuk soal nomor 2.

2. Di bawah ini tabel harga beras di Toko Makmur. Lengkapilah tabel tersebut
terlebih dahulu.
\begin{tabular}{|c|c|c|c|c|}
\hline Merk Beras & Harga & Bruto & Netto & Tara \\
\hline Putri Pink & $\operatorname{Rp~} 511.500,00$ & $50 \mathrm{~kg}$ & $49,3 \mathrm{~kg}$ & $\ldots$ \\
\hline Ber-Uang & $\operatorname{Rp} 509.700,00$ & $50 \mathrm{~kg}$ & $\ldots$ & $0,4 \mathrm{~kg}$ \\
\hline Towon & $\operatorname{Rp~} 512.300,00$ & $50 \mathrm{~kg}$ & $\ldots$ & $0,1 \mathrm{~kg}$ \\
\hline Pinkuin & $\operatorname{Rp} 510.000,00$ & $50 \mathrm{~kg}$ & $49,5 \mathrm{~kg}$ & $\ldots$ \\
\hline Raja Katak & $\operatorname{Rp~} 509.900,00$ & $50 \mathrm{~kg}$ & $\ldots$ & $0,2 \mathrm{~kg}$ \\
\hline
\end{tabular}

Ibu ingin membeli beras di Toko Makmur. Jika Ibu membawa uang $\mathrm{Rp}$ $515.000,00$, beras merk apa yang sebaiknya ibu beli? Berikan alasanmu!

Gambar 3. Soal Tes Nomor 2

Dalam mengerjakan soal nomor 2 tersebut, siswa terlebih dahulu mengisi tabel agar dapat memutuskan beras merk apa yang harus dipilih. Disana siswa dituntut secara tulis dan lisan dalam menjelaskan idenya dalam menentukan jawaban. Subjek pada kategori tinggi yaitu RM dan FD sudah benar dalam mengisi tabel dan memilih beras merk sesuai ide mereka. RM memilih beras Towon karena beras tersebut lebih menguntungkan dengan netto lebih banyak dan uang ibu masih cukup. FD memilih beras merk Raja Katak dengan alasan bahwa beras tersebut lebih menguntungkan denagn netto yang lumayan banyak dan harga yang murah. Berikut hasil wawancara RM dan FD.

Hasil wawancara subjek FD.

P $\quad$ : "Untuk soal no.2, tabel ini sudah kamu isi. Mengapa kamu memilih beras Raja Katak?”

FD : "Karena isinya lumayan banyak dan harganya gak seberapa mahal."

$P \quad \quad: \quad$ "Kenapa tidak memilih beras Towon kan isinya lebih banyak dari Raja Katak?"

FD : "Ya ... Karena harganya lebih mahal."

$P \quad$ : “Jadi yang paling menguntungkan adalah?”

FD : " "Beras Raja Katak.”

Hasil wawancara subjek RM

$P \quad$ : “Pada soal no.2, Mengapa kamu memilih beras merk Towon?”

RM : "Karena nettonya lebih banyak dan harganya Rp 512.300,00" 
P $\quad$ : "Mengapa tidak memilih beras merk Raja Katak kan nettonya selisih 0,1 dan harganya lebih murah?"

RM : "Iya kan nettonya lebih banyak dan uang ibu masih cukup"

Subjek pada kategori sedang yaitu DR dan NG menjelaskan idenya dengan baik. DR memilih beras merk Putri Pink karena tarra (berat pembungkus) lebih besar sehingga kualitas berasnya juga bagus. NG memilih beras merk Towon karena harganya paling mahal di antara lainnya sehingga kualitas beras bagus. Subjek pada kategori rendah yaitu SI dan DM kurang mampu dalam menjelaskan ide pada soal nomor 2 secara lisan maupun tulisan. Hal itu disebabkan, SI kurang mampu menjelaskan ide yang ia tulis sedangkan DM tidak menuliskan jawaban pada lembar soal dikarenakan kurang waktu. Namun pada hasil wawancara DM mampu menjelaskan ide yang ia dapatkan.

Berdasarkan penjelasan tersebut subjek kategori tinggi dan sedang mampu menjelaskan ide secara lisan dan tulis, sedangkan subjek kategori rendah kurang mampu dalam menjelaskan ide secara lisan dan tulis.

3. Menganalisis dan mengevaluasi pemikiran matematis dan strategi yang dipakai orang lain.

Pada indikator 3, soal yang dianalisis adalah soal nomor 3. Berikut bentuk soal nomor 3 .

\footnotetext{
3. Pak Bimo adalah penjual baju batik di daerah pasar Wiyung. Pak Bimo telah membeli secara grosiran sebanyak 500 potong baju batik dengan harga $\mathrm{Rp}$ 15.000.000,00. Namun Pak Bimo bingung berapa harga jual baju batik tersebut. Menurutmu berapa harga jual batik tersebut agar Pak Bimo bisa mendapatkan keuntungan? Jelaskan persentase keuntungannya!
}

\section{Gambar 4. Soal Nomor 3}

Pada soal nomor 3 tersebut, siswa bebas menyarankan keuntungan yang harus diambil dalam menjual setiap potong baju. Pada kategori tinggi yaitu subjek FD dan RM dapat menyelesaikan soal tersebut dengan cara dan jawaban yang berbeda. FD terlebih dahulu mencari harga satu potong baju kemudian menentukan harga yang tepat untuk dijual kembali. Berikut hasil soal tes siswa FD pada soal nomor 3.

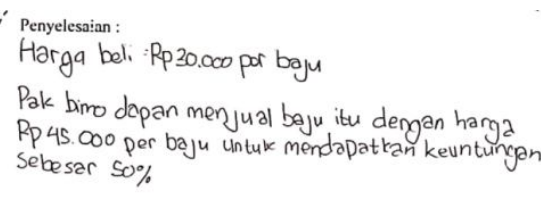

Gambar 5. Hasil Soal Tes FD Nomor 3 
Subjek RM menjawab soal nomor 3 dengan menentukan terlebih dahulu persentase keuntungan yang harus diambil kemudian menentukan harga per potong baju batik. Berikut hasil soal tes RM pada soal nomor 3.

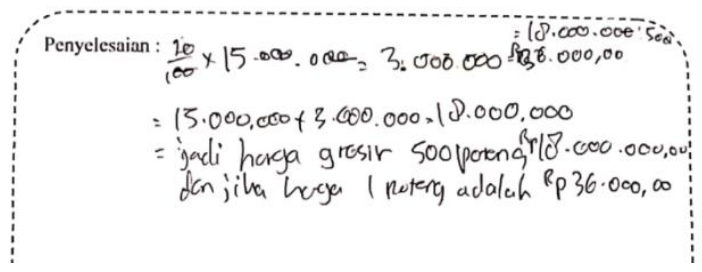

Gambar 6. Hasil Soal Tes RM Nomor 3

Selain dapat menyelesaikan soal nomor 3 dengan baik, subjek FD dan RM mampu menganalisis dan mengevaluasi alternative jawaban lain untuk soal nomor 3. Pada kategori sedang yaitu subjek DR dan NG. DR dapat menyelesaikan soal nomor 3 dengan baik dan menganalisis serta mengevaluasi alternative jawaban lain, sedangkan NG memberikan langkah-langkah yang benar hanya saja ada kesalahan dalam menghitung persentase. NG belum mampu menganalisis dan mengevaluasi alternative jawaban lain untuk soal nomor 3. Berikut wawancara NG.

$P \quad$ : "Untuk yang no.3, kan harga satu potongnya $\mathrm{Rp}$ 30.000,00 lalu kamu menyarankan menjual Rp 35.000,00, Apakah seperti ini cara menghitung persentase?”

$N G \quad:$ "Enggak."

$P \quad$ : "Betulkan dibawahnya sini, sehingga berapa persen keuntungan yang diperoleh?"

NG : “(sambil menghitung) jadi persentasenya16,6\% atau 17\%.”

$P \quad: \quad$ :Kira-kira ada keuntungan lain yang kamu dapatkan?"

NG : "Gak ada bu, biar simple."

Hal tersebut juga sama dilakukan oleh subjek pada kategori rendah. Dimana DM dan SI belum mampu menganalisis dan mengevaluasi alternative jawaban lain untuk soal nomor 3. DM dan SI tidak memberikan alternative jawaban atau solusi lain untuk soal nomor 3. Berdasarkan uraian tersebut subjek pada kategori tinggi mampu mampu menganalisis dan mengevaluasi alternative jawaban lain, subjek kategori sedang kurang mampu menganalisis dan mengevaluasi alternative jawaban lain, dan subjek kategori rendah belum mampu menganalisis dan mengevaluasi alternative jawaban lain.

\section{Kesimpulan}

Kemampuan komunikasi matematis siswa dapat kita ukur dengan memberikan aktivi- 
tas-aktivitas yang yang melibatkan siswa secara langsung baik dalam bentuk lisan maupun tulisan. Kedua bentuk itu saling mendukung agar tercipta kesesuaian dalam komunikasi matematis. Dari hasil dan pembahasan disimpulkan bahwa kemampuan komunikasi matematis siswa dalam menyelesaikan soal open ended pada materi aritmetika sosial kelas VII SMP di kelas VII-H SMPN 28 Surabaya dapat dikatakan baik. Hal itu dikarenakan sebagai berikut.

1) Siswa pada kategori tinggi mampu menyatakan peristiwa sehari-hari dalam bahasa atau simbol matematika (IDK 1), menjelaskan ide, situasi dan relasi matematik, secara lisan dan tulisan dengan benda nyata, gambar, grafik dan aljabar (IDK 2), dan menganalisis dan mengevaluasi pemikiran matematis dan strategi yang dipakai orang lain (IDK 3).

2) Siswa pada kategori sedang mampu menyatakan peristiwa sehari-hari dalam bahasa atau simbol matematika (IDK 1), menjelaskan ide, situasi dan relasi matematik, secara lisan dan tulisan dengan benda nyata, gambar, grafik dan aljabar (IDK 2), dan kurang mampu menganalisis dan mengevaluasi pemikiran matematis dan strategi yang dipakai orang lain (IDK 3).

3) Siswa pada kategori rendah mampu menyatakan peristiwa sehari-hari dalam bahasa atau simbol matematika (IDK 1), kurang mampu menjelaskan ide, situasi dan relasi matematik, secara lisan dan tulisan dengan benda nyata, gambar, grafik dan aljabar (IDK 2), dan belum mampu menganalisis dan mengevaluasi pemikiran matematis dan strategi yang dipakai orang lain (IDK 3).

\section{Ucapan Terimakasih}

Ucapan terimakasih ditujukan pada pihak-pihak yang telah mendukung keterlaksanaan penelitian ini.

\section{Daftar Pustaka}

Elida, Nunun. 2012. "Meningkatkan Kemampuan Komunikasi Matematik Siswa Sekolah Menengah Pertama Melalui Pembelajaran Think-Talk-Write (TTW)". Infinity Jurnal Ilmiah Program Studi Matematika STKIP Siliwangi. Bandung, Vol 1, No.2, September 2012. hal. 178-185.

Herdian. 2010. Kemampuan Komunikasi Matematika. (Online). https://herdy07.wordpress.com/2010/05/27/kemampuan-komunikasi-matematis/. Diakses: 2 Pebruari 2019. 
Herdiman, Indi. 2017. "Penerapan Pendekatan Open-Ended untuk Meningkatkan Penalaran Matematik Siswa SMP”. STKIP Siliwangi Bandung, Cimahi. JES-MAT, Vol. 3 No. 2 September 2017: ISSN 2460-8904. Hal. 195-204.

Hodiyanto. 2017. "Kemampuan Komunikasi Matematis dalam Pembelajaran Matematika". AdMathEdu | Vol.7 No.1 | Juni 2017. hal. 9-18.

National Council of Teachers of Mathematics. 2000. Principles and Standards for School Mathematics. NCTM: Reston VA.

Ruslan, A.S, Santoso, B. 2013. "Pengaruh Pemberian Soal Open-EndedTerhadap Kemampuan Penalaran Matematis Siswa”. Jurnal Kreano. ISSN : 2086-2334. Diterbitkan oleh Jurusan Matematika FMIPA UNNES. Volume 4 Nomor 2 Bulan Desember Tahun 2013. hal. 138-150.

Sroyer, Agustinus. 2013. "Pendekatan Open-Ended (Masalah, Pertanyaan dan Evaluasi) dalam Pembelajaran Matematika". Delta-Pi: Jurnal Matematika dan Pendidikan Matematika. Vol. 2, No. 2, Oktober 2013 : ISSN 2089- 855. Hal. 29-37.

Subekti, Fitrianto Eko; Untarti, Reni; Muhammad, Alim. 2016. "Deskripsi Kemampuan Komunikasi Matematis Mahasiswa pada Mata Kuliah Statistik Pendidikan”. Prodi Pendidikan Matematika Unswagati Cirebon. Jurnal Euclid: ISSSN 2355-1712, vol. 2, No.2, pp.263-274.

Umar, Wahid. 2012. "Membangun Kemampuan Komunikasi Matematis Dalam Pembelajaran Matematika". Infinity Jurnal Ilmiah Program Studi Matematika STKIP Siliwangi. Bandung, Vol 1, No.1, Februari 2012.

Wijayanto, Agus Dwi; Fajriyah, Siti Nurul; Anita, Ika Wahyu. 2018. "Analisis Kemampuan Komunikasi Matematis Siswa SMP pada Materi Segitiga dan Segiempat". Journal Cendekia: Jurnal Pendidikan Matematika. Volume 2, No. 1, Mei 2018, pp. 97-104. E-ISSN : 2579-9258 P-ISSN : 2614-3038.

Yusuf, Mariska; Zulkardi; Saleh, Trimurti. 2009. "Pengembangan Soal Soal Open-Ended Pada Pokok Bahasan Segitiga dan Segiempat Di SMP”. Jurnal Pendidikan Matematika. Volume 3. No. 2 Desember 2009. hal. 47-56. 